\title{
TPACK Constructs: A Sustainable Pathway for Teachers Professional Development on Technology Adoption
}

\author{
Michael Nkwenti Ndongfack \\ Department of Computer Science and Educational Technologies, Higher Teacher Training College, University of \\ Yaounde I, Yaounde, Cameroon \\ Email: mikesman2002@yahoo.com, nkwenti@ens.cm
}

Received 30 July 2015; accepted 13 September 2015; published 16 September 2015

Copyright (C) 2015 by author and Scientific Research Publishing Inc. This work is licensed under the Creative Commons Attribution International License (CC BY). http://creativecommons.org/licenses/by/4.0/

(c) (i) Open Access

\section{Abstract}

As numerous Information and Communication Technologies (ICTs) penetrate various facets of life, teachers are underutilising it in the teaching and learning process. With the introduction of ICTs in the Cameroon primary school curriculum, teachers have been receiving training on computer skill-base courses and yet many are unable to adopt the tool in instructional processes. To ensure that teacher training programmes effectively assist them in integrating technology in instructional processes, a study was initiated to determine additional set of skills that they need to adopt the tool in their classrooms. This study employed a quantitative survey methodology in the collection of data towards the determination of additional skills needed by primary school teachers. A total of 400 teachers were selected using the stratified random sampling technique from primary schools across all the 10 Regions of Cameroon. The data were analysed using mean and standard deviation. The findings of the survey indicated that teacher-participants reported a better mastery of content knowledge (CK), pedagogy knowledge (PK), pedagogical content knowledge (PCK) and technological content knowledge (TCK). On the other hand, they reported weaknesses in three other constructs notably: technology knowledge (TK), technological pedagogical knowledge (TPK), and technological pedagogical content knowledge (TPACK). The researcher concluded that teacherparticipants performed better in the CK, PK and PCK because these constructs constitute the basis for teacher education in Cameroon. Similarly, they performed well in the TCK construct because their professional development programme is focused on fostering their computer knowledge as a standalone skill. Their poor performance in the TK, TPK and TPACK stems from the fact that the training programmes do not lay emphasis on these constructs. To provide a sustainable teacher professional development programme on technology adoption, it was therefore recommended that stakeholders involved in the sector design training packages that focus on the TPACK constructs. This will foster teachers' adoption of the tool for instructional purposes. 


\section{Keywords}

\section{TPACK, Technology Adoption, Teacher Professional Development, Technology Skills}

\section{Introduction}

In today's society, new social practices have emerged due to the proliferation and increased use of innovative digital technologies (Buckingham \& Willett, 2006). Although these technologies are rapidly penetrating every facet of societal life, the rate at which it is used in education to improve learning outcomes is still very low (Nkwenti Ndongfack, 2014). Every citizen requires additional sets of skills to cope with the new social practices and to effectively participate in the knowledge economy (Kalantzis \& Cope, 2008; Partners for 21st Century Skills, 2009). These skills include the ability to use Information and Communication Technology (ICT), herein referred to as technology to identify important questions, locate information, critically evaluate the usefulness of information, synthesize the information to answer questions, and communicate the information to others (Leu, Kinzer, Coiro, \& Cammack, 2004; Organisation for Economic Co-operation and Development [OECD], 2009). Because of the significant contributions of ICT in transforming traditional practices and the need for pupils to acquire the above mentioned skills, most educational systems around the world resolved to integrate them in the school curriculum (Kozma, 2005).

In 2007, the Cameroon Ministry of Basic Education put in place an ICT Policy and Strategy Plan outlining guidelines for the development of technology in schools. The plan envisaged the production of an ICT-literate workforce which will acquire thinking, learning and communication skills to respond to the demands of the 21st century. With clear policy objectives put in place to develop ICT across the school curriculum, the government and her development partners are gradually equipping schools with the required ICT resources (Nkwenti Ndongfack, 2010). Teachers are equally being trained through cascaded approach to teach, using technology (Inspectorate of Pedagogy in Charge of ICT Annual Report, 2010; Nkwenti Ndongfack, 2015). Although ICTs are gradually being made available in classrooms, teachers who have access to them in their schools underutilise the tools for instructional purposes. Pupils from homes with access to computers and internet connection are more technology-savvy than their teachers. This category of pupils poses a lot of challenges to their teachers when it comes to using technology in classrooms (Inspectorate of Pedagogy in Charge of ICT Annual Report, 2011; Nkwenti Ndongfack, 2014). Teachers' inability to handle them has been largely blamed on inadequate or no professional development of teachers (Fru, 2011; Karsenti, Collin, \& Harper-Merrete, 2012). This paper investigates the type of additional skills in-service primary school teachers' need in order to adequately adopt technology in the teaching and learning process.

\section{Weaknesses in the Teachers Professional Development on Technology Adoption}

The Cameroon's Ministry of Basic Education’s ICT Policy and Strategy Plan (Republic of Cameroon, 2007: p. 18) recommends that trainee teachers leaving the Teacher Training Colleges must be computer literate, defined as being able to use a computer safely to:

- compose a document using word processing functions;

- prepare spread sheets to track school activities;

- prepare a database to store and keep track of school information;

- prepare presentations using specialised software;

- send and receive electronic mail messages;

- access sites in the Internet and collect educational materials; and

- create learning platforms for pupils, etc.

From the objectives outlined above, it can be observed that the policy laid emphasis only on ICT knowledge and skills training among teachers with nothing said about integrating them in instructional processes. Over the years, teachers' professional development programmes have been skill-based with training focused on attaining policy goals as outlined above (Inspectorate of Pedagogy in Charge of ICT Annual Report, 2009, 2010, 2011).

Valanides \& Angeli (2006) upheld that the task of training teachers to effectively integrate technology in 
classroom practices is undoubtedly complex. A review of some literatures on teachers' adoption of technology in instructional processes indicates that, to a greater extent, ICT professional development for teachers has mostly centred on learning about technology. The main focus being skills development on the use of various computer applications, such as word processing, spread sheets, email, internet, and graphics design (Harris, Mishra, \& Koehler, 2009; Lieberman \& Pointer Mace, 2008; McDonald, 2009; Mishra \& Koehler, 2006; Nkwenti Ndongfack, 2015). Although basic computing skills constitute the cornerstone of ICT knowledge, skills-based courses are not enough to prepare teachers to integrate ICTs in classroom instructional processes as they are usually taught in isolation from a pedagogical context (Harris et al., 2009). Professional development models that do not take into consideration subject-specific pedagogy and the context of application will lead to teachers having difficulties to link technology with pedagogy (Harris et al., 2009; Mishra \& Koehler, 2006). This accounts for the reason why many teachers who received ICT training as part of their professional development still lack the confidence needed to integrate ICT in the teaching and learning process (Harris et al., 2009; Harrison et al., 2002). These reviews seem to indicate that although Cameroon in-service primary school teachers have been trained on computer skill-based courses, these might be insufficient to empower them adopt the tool for instructional purposes. Based on these weaknesses, this study was conducted with the following research question in mind:

What additional set of skills do in-service primary school teachers require to adequately adopt technology in the teaching and learning process?

\subsection{Sustainable Pathway for Technology Adoption}

According to Mishra \& Koehler (2006), the gaps identified in computer skilled-based programmes can be bridged by redesigning the training packages to focus on Technological Pedagogical Content Knowledge (TPACK). Harris \& Hoffer (2011) remarked that for teachers to adequately integrate technology across different subject areas in the school curriculum, they need to demonstrate a firm mastery of TPACK. TPACK is an amalgamation of teachers' knowledge of curriculum content, general pedagogies, technologies, and contextual factors that influence learning (Koehler \& Mishra, 2008). One approach through which teachers can acquire skills to effectively adopt technology in the classroom is by working through different stages of professional development to blend technology, content and pedagogy (Niess, Ronau, Shafer, Driskell, Harper, Johnston, \& Kersaint, 2009). While reviewing the model suggested by Niess and colleagues, four major themes emerged from their proposed TPACK developmental model: curriculum and assessment; learning; teaching and access. Figure 1 shows that, teachers with sufficient background in pedagogical content knowledge (PCK) go through the stages of recognising, accepting, adapting, exploring and advancing with technology for each of the four major themes. As teachers progress through the model, their TPACK is enhanced (Niess et al., 2009). The figure also illustrates how the constructs of content, pedagogy and technology intersect through progression in the different stages of the TPACK developmental model.

Recognising stage: As seen in Figure 1, at the recognizing stage of TPACK development, teachers begin to

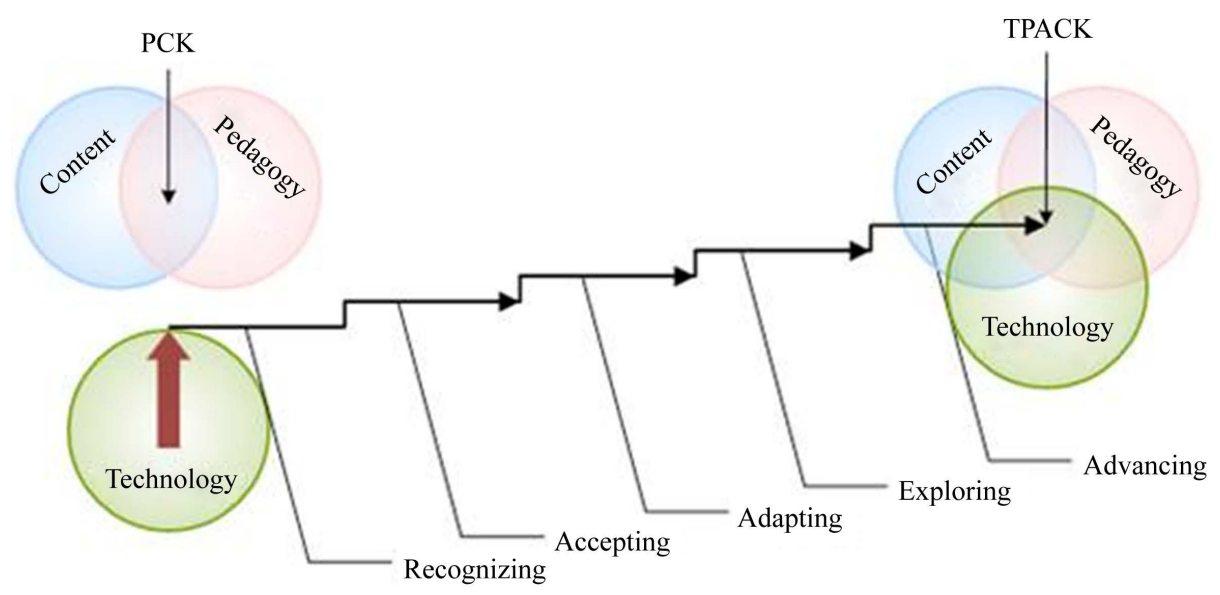

Figure 1. Representation of the TPACK development stages extracted from Niess et al. (2009). 
use basic technologies and recognise their potential in enhancing teaching and learning in various subject areas. At this stage, teachers hardly use technology to introduce a new concept or to carry out pupils' assessments. The teachers still believe that the use of technology is time-consuming and as such will hinder them from covering their syllabuses. They are apt to use technology only when they are sure that they will have enough time to cover their programmes or when pupils demonstrate a mastery of the content knowledge (Niess et al., 2009).

Accepting stage: Niess et al. (2009) remarked that teachers in the accepting stage of TPACK development accept the technology as being inevitable in their daily practices. When they see the benefits of using technology to enhance the teaching and learning process, they begin to integrate it in their lesson though with many difficulties to incorporate it in all subject areas. Faced with these challenges, the teachers begin to seek professional development opportunities on technology integration. Their participation in such training enables them to start trying out the skills learned in their classrooms. The teachers gradually allow pupils to use technology to illustrate their understanding. The limited authorisation of the pupils to use technology often arises as a result of teachers' worries that they may be distracted from paying attention to their lessons. At this stage, they have serious challenges managing their classes with the availability of technology. The technology use in these teachers' classes is usually skill-based with teacher-led, step-by-step directions.

Adapting stage: At this stage, the teachers start demonstrating understanding of the benefits of using technology as a teaching and learning tool. They begin to explore and experiment with technology as tools that enhance curriculum practices. Most often, the experimentation process determines the full adoption or rejection of the tool. They develop some lessons in which pupils can use technology to explore and improve their understanding of previously learned concepts. Prior to letting pupils experiment with technologies, the teachers regularly start by illustrating the use of the technology to pupils while cautioning on safety issues. They design basic technology driven assessments to evaluate learners' conceptual understandings in addition to procedural understandings. These teachers also try to integrate ideas learned from professional development sessions, but adapt the ideas to meet the needs of their pupils (Niess et al., 2009).

Exploring stage: The exploring stage of TPACK development according to Niess et al. (2009) corresponds to a phase where technology-motivated teachers begin to review traditional lesson plans of various subject areas to integrate ICT. As they navigate through the process, they identify which technology to integrate in a lesson plan to facilitate pupils understanding of lesson concepts. Through the use of technology, these teachers facilitate pupils’ learning by engaging them in critical thinking, explorations, problem solving and decision making. With pupils' learning and attitudes as a guiding factor, they "plan, implement and reflect on teaching and learning outcomes" (Niess et al., 2009: p. 12). These teachers "share classroom-tested, technology-based lessons, ideas and successes with peers” (Niess et al., 2009: p. 23). Furthermore, they organise themselves into groups to explore which curriculum area will require the use of technology to clarify abstract concepts. Likewise, the teachers share their experiences of using technology in different subject areas with peers during staff meetings and also design technology-driven assessments to facilitate the evaluation of pupils' understandings (Niess et al., 2009).

Advancing stage: In the advancing stage of TPACK development, teachers understand the need to innovate various aspects of the school curriculum with technology. They proceed with the modification of the school curriculum to integrate technology in every subject area. Their focus at this stage is the enhancement of learners' level of understanding through engaging them in high-level thinking and self-directed learning.

Advancing teachers fully embrace technology and view it as a tool that facilitates the accessibility to additional learning materials that further enhances pupils' understanding in various subjects in the school curriculum. Niess et al. (2009: p. 22) observed that this category of teachers "plan, implement and reflect on teaching and learning with concern and personal conviction for pupils' thinking and understanding of the lesson to be enhanced through integration of the various technologies”. Besides, these highly motivated teachers are perceived by their peers as very resourceful with novel ideas for teaching and learning with technology. They are often solicited by their less knowledgeable colleagues to help them through the difficulties they faced in integrating technology in the curriculum (Niess et al., 2009).

Figure 1 is the TPACK developmental model that illustrates a better way of assessing teachers' technology integration skills. It analyses teachers' activities in terms of four major themes that occur in the classroom context. In presenting this model, Niess et al. (2009) noted that TPACK development is not a one-time progression. Rather, it is an iterative process that teachers go through as they encounter new technologies which may be used as learning tools. Through the various stages of TPACK development, a teacher moves from recognizing the 
benefits of a technology in accomplishing the goals of a given subject area to accepting its use, adapting lessons to include use of the technology, exploring more areas in the curriculum where the technology could be used and finally to advancing the depth of the curriculum under study through the use of the technology. The exploring and advancing stages of TPACK development have a high focus on learners' thinking. In these stages, teachers design, implement and reflect on technology lessons and share proven technology lesson ideas with peers. This could become a sustainable pathway for preparing Cameroon's primary school teachers to adopt technology in instructional processes.

\subsection{TPACK in Teacher Professional Development Programmes}

Since Technological Pedagogical Content Knowledge was developed as a framework that guides the development of teachers' knowledge in the integration of ICT across the school curriculum, several researchers have used the framework for different purposes. The available research regarding TPACK development is limited primarily to pre-service teachers; however, some research is available to give insight into in-service teachers and their TPACK. Richardson (2009) studied twenty middle school teachers in six schools. These teachers participated in professional development that sought to increase their TPACK. Data was collected through journal entries, observations, and interactions during professional development activities. The study revealed a need for professional development to focus on connecting content to technology and pedagogy, as well as focusing on the multiple representations technology offers. During exit interviews, teachers exhibited a positive disposition toward instructional technologies and also communicated that they perceived an increase in TPACK as they went through the professional development programme.

Niess (2008) used the TPACK framework to administer professional development to mathematics teachers on the use of ICT as a pedagogic tool. The study concluded that the majority of teachers testified that the framework was very useful in developing not only their knowledge on the use of the tool in mathematics but also empowered them to develop the most needed 21st century skills.

At Arizona State University, researchers created a faculty development package based on TPACK. The programme helped faculty staff design uses of Web 2.0 and social networking capabilities for their teacher education courses. Results from suggest that faculty members appreciated the focus on content and pedagogy, as well as technology, and that in some cases faculties were altering their content and/or pedagogy as a result of their ability to afford the technology (Archambault, Wetzel, Foulger, \& Williams, 2010). The TPACK framework for the work thus helped in moving the focus from using social networking tools to designing uses of social networking tools that enhance content and pedagogy.

Schmidt, Seymour, Sahin, \& Thompson (2008) also reflected on TPACK development in PreK-6 Teachers. The researchers observed that TPACK framework acted like a new form of knowledge that requires teachers not only to understand the complexity of relations between technology, pedagogy and content, but also proposes solutions for their practices.

Avidov-Ungar \& Nagar (2015) explore the TPACK framework within the implementation of the ICT programme, to examine how the ICT instructors perceive the encouraging and inhibiting factors of the change implementation, and to examine the factors predicting external district ICT instructors' sense of empowerment in comparison with internal school ICT instructors. The focus was to examine the knowledge power PICTK (Program Information Communication Technology Knowledge) and TPACK knowledge (Technological Pedagogy and Content Knowledge) on the sense of empowerment within them. The research findings clarify that the ICT instructors' sense of empowerment improves by enhancing their PICTK and TPACK knowledge. This sense of empowerment helps the instructor in creating viewpoints on the implementation process and the National Programme outcome. The researchers concluded that the ICT instructors' viewpoints have unique significance to understanding the change elements that the National ICT Programme created in the schools. It was therefore recommended that they continue to encourage ICT instructors to expand their personal knowledge on the developing ICT programmes.

\section{Theoretical Framework}

According to Shulman (1986), effect teachers should demonstrate a firm mastery of content and pedagogy knowledge in order to effectively teach in their classrooms. Based on this view, Shulman introduced the concept of pedagogical content knowledge (PCK) as the way pedagogy and content knowledge can be blended to pro- 
vide an understanding on how particular topics can be represented and adapted to pupils' characteristics, interests and abilities. Shulman (1987, 1986: p. 9) argued that PCK is the understanding of what makes the learning of specific concepts easy or difficult and "embodies the aspects of content most germane to its teach-ability". As various ICTs started gaining the central stage in education, Mishra \& Koehler (2006) proposed the integration of technology into Shulman's (1987) PCK model and named the resulting combination, Technological Pedagogical Content Knowledge (TPACK). Teaching successfully with technology requires continually creating, maintaining, and re-establishing a dynamic equilibrium between the components of technology, pedagogy and content.

The Technological Pedagogical Content Knowledge (TPACK) framework (Figure 2) provides a better approach for studying the complexity involved in integrating technology into different subject area (Mishra \& Koehler, 2006). It attempts to illustrate the fundamental knowledge teachers need in order to adopt technology effectively in their classrooms. The framework present the knowledge teachers need to teach with and about technology across the school curriculum and in different levels of education. At the centre of the TPACK framework, is the amalgamation of three primary forms of knowledge: Content Knowledge (CK), Pedagogical Knowledge (PK), Technological Knowledge (TK) and their intersections with each other (Nkwenti Ndongfack, 2014).

Content knowledge (CK) is knowledge about the actual subject matter that is to be learned or taught (Mishra \& Koehler, 2006; Harris, Mishra, \& Koehler, 2009). Different levels of an educational system such as the primary and secondary have a way of structuring their content. The degree of difficulty of the content varies as the level of education or grade level increases thus necessitating the teacher to a have strong mastery of content knowledge. As Shulman (1986) noted, content knowledge would include: knowledge of concepts, theories, ideas, organizational frameworks, knowledge of evidence and proof, as well as established practices and approaches towards developing such knowledge.

Pedagogical knowledge (PK) is deep knowledge of the processes and practices or methods of teaching and learning and how it encompasses, among other things, overall educational purposes, values, and aims (Mishra \& Koehler, 2006). It also includes knowledge of different theories about learning, learning styles, planning,

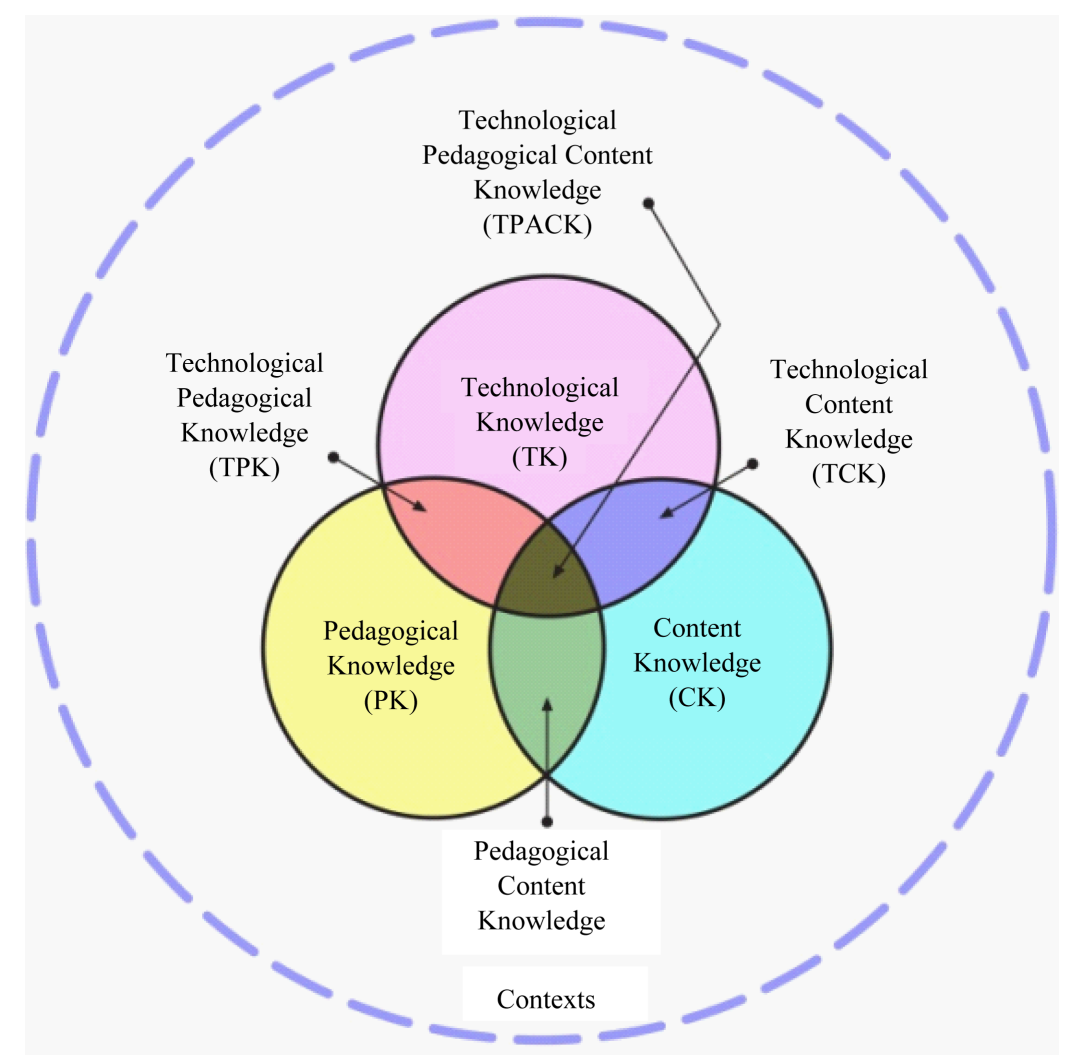

Figure 2. The TPACK framework and its knowledge components extracted from Harris, Mishra, \& Koehler (2009). 
management and evaluation. Furthermore, it includes knowledge about techniques or methods used in the classroom; the nature of the target audience; and strategies for evaluating pupils' understanding (Kanuka, 2006). A teacher with deep pedagogical knowledge understands how pupils construct knowledge and acquire skills, and how they develop habits of the mind and positive dispositions towards learning. As such, pedagogical knowledge requires an understanding of cognitive, social and developmental theories of learning and how they apply to pupils in the classroom (Harris et al., 2009).

Pedagogical content knowledge (PCK) is knowledge of how to combine pedagogy and content effectively, as conceptualized by Shulman (1987). Central to Shulman's conceptualization of PCK is the notion of the transformation of the subject matter for teaching. According to Shulman (1987), this transformation occurs as the teacher interprets the subject matter, finds multiple ways to represent it, and adapts and tailors the instructional materials to alternative conceptions and pupils’ prior knowledge. Mishra \& Koehler (2006) held that this works well if teachers know the teaching approach that fit the content and how elements of the content are arranged for better understanding.

Technology knowledge (TK) is knowledge about standard technologies used in the instructional process such as books, chalk and blackboard to more advanced technologies such as the computer, internet connection and digital video (Mishra \& Koehler, 2006; Harris et al., 2009). TK does go beyond digital knowledge to having knowledge of how to change the purpose of existing technologies so that they can be used in a technologyenhanced learning environment. The integration of technology in teaching and learning requires a deeper understanding of the complex set of interrelationships between pedagogy, content, tools, learners, and context (Mishra \& Koehler, 2006).

Technological Content Knowledge (TCK) deals with the manner in which technology and content are reciprocally related. TCK helps teachers imagine instances where technology can be effectively integrated into their teaching (Mishra \& Koehler, 2006). Although technology constrains the kinds of representations possible, newer technologies often afford newer and more varied representations and greater flexibility in navigating across these representations (Mishra \& Koehler, 2006). For example, significant developments can be realized by using computer simulations in subject areas where pupils have difficulties to understand. In teaching the planetary system in a geography lesson for example, a teacher can use a computer simulation programme to illustrate what happens in space.

Technological pedagogical knowledge (TPK) requires an understanding of general pedagogical strategies applied to the use of technology (Koehler \& Mishra, 2009). Furthermore, it is knowledge of the existence, components, and capabilities of various technologies as they are used in teaching and learning settings, and conversely, knowing how teaching might change as the result of using particular technologies. Koehler \& Mishra (2009) observed that majority of popular computer software are not designed for educational purposes. They are produced for businesses, entertainment, communications, and social-interaction purposes. Thus this knowledge will include the understanding of how the software created for other purposes can be used to achieve an educational goal. The ability to choose an ICT based on its usefulness and strategies for using the tool; knowledge of pedagogical strategies and the ability to apply those strategies for use of technologies; knowledge of tools for maintaining class records, attendance, and grading, and knowledge of generic technology-based ideas such as discussion boards like forums and chat rooms (Mishra \& Koehler, 2006).

Technological Pedagogical Content Knowledge (TPACK) is thus a framework to understand and describe the kinds of knowledge needed by a teacher for effective pedagogical practice in a technology enhanced learning environment (Harris \& Hoffer, 2009). It is an emergent form of knowledge that goes beyond all three components (content, pedagogy and technology). TPACK is the basis for effective use of technology in teaching and a condition for efficient adoption of ICT in the teaching and learning process (Koehler \& Mishra, 2008). This knowledge is different from knowledge of a particular subject and also from the general pedagogical knowledge shared by teachers across disciplines. A better application of TPACK requires an understanding of the representation of concepts using technologies; pedagogical techniques that use technologies in constructive ways to teach content; knowledge of what makes concepts difficult or easy to learn and how technology can help redress some of the problems that pupils face; understanding of pupils' prior knowledge and theories of epistemology; and knowledge of how technologies can be used to build on existing knowledge and to develop new epistemologies or strengthen old ones (Koehler \& Mishra, 2008). Thus, teachers need to develop competencies and be cognitively flexible enough in not only each of these key domains ( $T, P$, and $C$ ) but also in the manner in which these domains interrelate so that they can be able to implement them in diversi- 
fied situations (Harris et al., 2009).

Harris et al. (2009) cautioned that teaching with technology is a difficult thing to do and thus the TPACK framework suggests that Content, Pedagogy, and Technology have roles to play individually and collectively. Teaching successfully with technology requires continually creating, maintaining, and re-establishing a dynamic equilibrium between each component.

Since the in-service primary school teachers' professional development programme was initially focused on skill-based training, TPACK is used in this study to guide the evaluation of teachers Technological Pedagogical Content Knowledge. This will enable us to clearly discern what skills they need to sustainably adopt technology in their classrooms.

\section{Methodology}

The study employed quantitative research methodology in the determination of the skills teachers need to adopt technology in the teaching and learning process. According to the Ministry of Basic Education Statistical Year Book (2011), there are 53,452 government primary school teachers teaching in 14,712 primary schools nationwide. Regarding the teaching staff, $57 \%$ of them are female while $43 \%$ are male; $50 \%$ of the teachers teach in urban schools, $30 \%$ teach in semi urban schools and $20 \%$ teach in rural schools. To get an appropriate sample size for the study, the Research Advisors (2006) spreadsheets application was used. The results study yielded 382 teachers thus approximately 218 females and 164 males at a confidence level of 95\% and a margin of error (degree of accuracy) of 5\%. For easy distribution of the sample size across the ten Regions and taking into consideration gender and location of the teachers, the researcher increased the number to 400 (230 females and 170 males) teachers which is greater than the minimum sample size suggested by Research Advisor (2006). Table 1 indicates the demographic information of teacher-participants in terms of gender, age, and teaching experience. The bulk of the participants were females because $52.5 \%$ of teachers in Cameroon primary schools are females.

The sample size for schools yielded 378 as per the Research Advisor application at the same confidence interval. The Statistical Year Book reveals that, 38\% of the primary schools are in urban settlements; $22 \%$ in semiurban settlements and $40 \%$ are in rural settlements. To ensure that the schools where the teacher-participants will be drawn from are adequately distributed, proportionate sampling technique was applied in the selection of schools from each region taking into consideration the type of settlement (Moore \& McCabe, 2005). A Proportionate sampling technique is used when the researcher knows the distribution of target schools or population across a set of groups and when there is a desire to ensure that minorities are properly represented in the study. This guideline enabled the researchers to identify the groups to be used for the sub-segments and the proportion of the population in each group. To get the sample for each group, the percentages were multiplied by the total sample size. Table 2 indicates the distribution of participating schools per Region in terms of school location. The Centre Region had the highest number of schools because it has the highest number of schools. It is worth noting that the schools were distributed in terms of the number of schools in each Region.

Table 1. Demographic information of teacher-participants.

\begin{tabular}{|c|c|c|c|c|c|}
\hline \multirow[t]{2}{*}{ Description } & & \multicolumn{2}{|c|}{ Male } & \multicolumn{2}{|c|}{ Female } \\
\hline & & Frequency & Percentage & Frequency & Percentage \\
\hline Participants & & 170 & 42.5 & 230 & 57.5 \\
\hline \multirow[t]{3}{*}{ Age } & $<32$ years & 57 & 14.25 & 72 & 18 \\
\hline & $\geq 32$ years & 113 & 28.25 & 158 & 39.5 \\
\hline & $\leq 5$ years & 44 & 11 & 67 & 16.75 \\
\hline \multirow{3}{*}{$\begin{array}{l}\text { Teaching } \\
\text { experience }\end{array}$} & 6 - 10 years & 49 & 12.25 & 53 & 13.25 \\
\hline & 11 - 15 years & 44 & 11 & 60 & 15 \\
\hline & $\geq 15$ years & 33 & 8.25 & 50 & 12.5 \\
\hline
\end{tabular}


Table 2. Number of participating schools from each region in terms of school location.

\begin{tabular}{|c|c|c|c|c|}
\hline \multirow{2}{*}{ Region } & \multirow{2}{*}{ Number of primary schools } & \multicolumn{3}{|c|}{ School location } \\
\hline & & Rural & Semi-Urban & Urban \\
\hline Adamawa & 22 & 9 & 5 & 8 \\
\hline Centre & 65 & 26 & 14 & 25 \\
\hline East & 23 & 9 & 5 & 9 \\
\hline Far North & 50 & 20 & 11 & 19 \\
\hline Littoral & 43 & 17 & 9 & 17 \\
\hline North & 29 & 12 & 6 & 11 \\
\hline North West & 49 & 19 & 11 & 18 \\
\hline West & 47 & 19 & 10 & 18 \\
\hline South & 29 & 12 & 7 & 11 \\
\hline South West & 21 & 8 & 5 & 8 \\
\hline Total & 378 & 151 & 83 & 144 \\
\hline
\end{tabular}

\section{Data Collection}

Quantitative data was collected through a nation-wide survey involving 400 in-service primary school teachers. To respond to the research question, survey questionnaires containing Likert Scale items were administered to 400 teacher-participants selected using the stratified random sampling technique from the 10 Regions of Cameroon.

The questionnaire included:

- Demographic items related to name of the school, gender, age and teaching experience;

- Seven Technology Knowledge (TK) items;

- Twelve Content Knowledge (CK) items;

- Seven Pedagogical Knowledge (PK) items;

- Four Pedagogical Content Knowledge (PCK) items;

- Four Technological Content Knowledge (TCK) items;

- Four Technological Pedagogical Knowledge (TPK) items;

- Six Technological Pedagogical Content Knowledge (TPACK) items;

Each item in the sets of questionnaires was rated with a 5-point Likert-scale with each response associated with a numeric value ( 1 to 5 ) to ensure the reliability of measurement (Thorndike, 2005). The responses to the questionnaire were anonymous. The instruments were adapted from previous similar studies in the field notably from Schmidt, Baran, Thompson, Koehler, Mishra, \& Shin (2009); Archambault \& Crippen (2009). To further guarantee the reliability of the data collection instruments, they were pilot tested with teachers not taking part in the study. The scores obtained from the returned pilot questionnaires were assessed using Cronbach's alpha (Hogan, Benjamin, \& Brezinski, 2000). The test items were designed to investigate teachers' knowledge of technology, pedagogy and content.

Statistical Package for Social Sciences version 17 was used to analyse the quantitative data in the form of mean and standard deviation.

\section{Findings}

Research question: What additional set of skills do in-service primary school teachers require to adequately adopt technology in the teaching and learning process?

To answer this research question, a total of 400 teacher-participants were surveyed on the seven TPACK knowledge constructs notably: Technological Knowledge (TK); Content Knowledge (CK); Pedagogical Knowledge (PK); Pedagogical Content Knowledge (PCK); Technological Content Knowledge (TCK); Technological 
Pedagogical Knowledge (TPK); and Technological Pedagogical Content Knowledge (TPCK). All the seven constructs were made up of 44 test items.

Figure 3 indicates the mean and standard deviation of survey conducted to determine the additional set of skills teachers need to adopt technology in instructional processes. It can be observed that the constructs of Technological Knowledge (TK), Technological Pedagogical Knowledge (TPK) and Technological Pedagogical Content Knowledge (TPACK), all scored a mean of less than $3.00(\mathrm{M}<3.00)$. The construct of Pedagogical Knowledge (PK), scored a mean greater than 3.00 ( $\mathrm{M}>3.00$ ) while the constructs of Content Knowledge (CK), Pedagogical Content Knowledge (PCK) and Technological Content Knowledge (TCK) all registered higher means $(\mathrm{M}>4.00)$.

\section{Discussion of Findings}

The research question was formulated to investigate the type of skills teacher-participants need in terms of technology, pedagogy and content knowledge. The respondents were surveyed on three knowledge domains: technology, pedagogy and content which were further broken down into seven constructs namely: Technological Knowledge (TK), Content Knowledge (TK), Pedagogical Knowledge (PK), Pedagogical Content Knowledge (PCK), Technological Content Knowledge (TCK), Technological Pedagogical Knowledge (TPK), and Technological Pedagogical Content Knowledge (TPACK). Mishra \& Koehler (2006) in a study had demonstrated that teachers can effectively teach with technology if they are able to blend technology, pedagogy and content knowledge. This assertion has been widely investigated and confirmed by other researchers in both pre and in-service teacher programmes (Niess, 2008; Archambault et al., 2010; Schmidt et al., 2008).

The findings of the survey indicated that teacher-participants reported a better mastery of content knowledge (CK), pedagogy knowledge (PK), pedagogical content knowledge (PCK) and technological content knowledge (TCK). In the researcher's view, this can be justified by the fact that before the introduction of technology in 2007 in the pre-service teachers' training programme, their curriculum was essentially focused on developing their knowledge of pedagogy and content. Shulman (1986) introduced Pedagogical Content Knowledge (PCK) in teachers' programmes as an approach that relates to the transformation of several types of knowledge. These types of knowledge include an understanding of what makes the learning of specific concepts easy or difficult. More explicitly, PCK is based on assisting teachers to critically reflect on and interpret the subject matter; find multiple ways to represent the information as analogies, metaphors, examples, problems, demonstrations, and/or classroom activities; adapt the material to pupils' developmental levels and abilities, gender, prior knowledge, and misconceptions; and finally tailor the material to those specific individuals or groups of pupils to whom the content will be taught. Pre-service teachers, upon graduation must demonstrate a mastery of pedagogy and content knowledge. Given that their professional development programme has been computer skill-based, they equally demonstrated a strong mastery of technological content knowledge (ICT Policy and Strategy Plan for Basic Education, 2007).

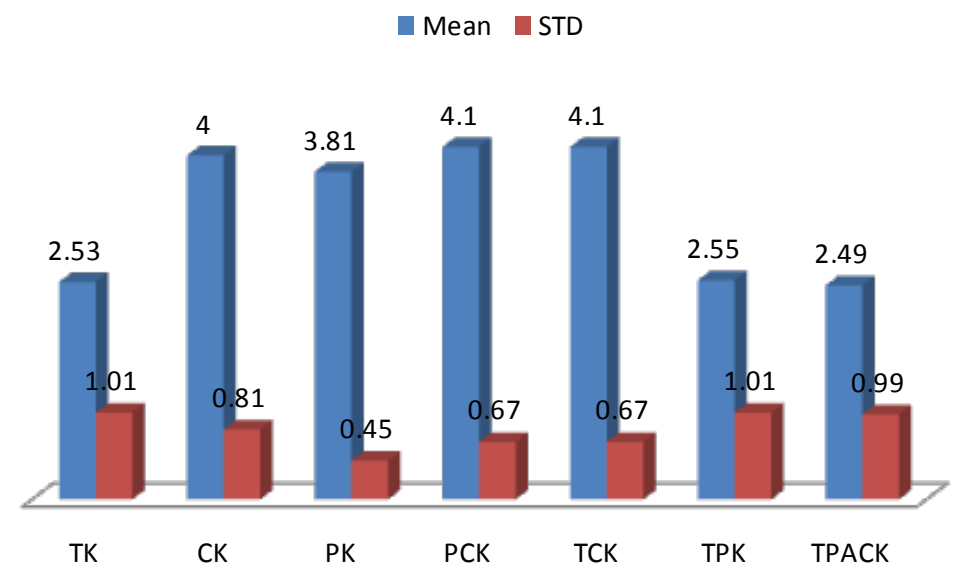

Figure 3. Mean and standard deviation of each construct in the nationwide survey. 
On the other hand, the survey findings indicated that teacher-participants reported weaknesses in three other constructs notably TK, TPK, and TPACK. These weaknesses in the researcher's opinion can be justified by the fact that most teachers graduated from the pre-service programme when ICT had not yet been introduced in their curriculum. A majority of the in-service primary school teachers have been practising for more than five years as observed in the demographic information of those who took part in the study. Besides, the pre-service teachers' ICT curriculum does not lay emphasis on blending technology, pedagogy and content knowledge. Its focus is on teaching some basic computer skills using Microsoft Office applications as a standalone programme. Several researchers have warned that although basic computing skills constitute the cornerstone of ICT knowledge, skill-based courses are not enough to prepare teachers to integrate ICT in classroom instruction as they are usually taught in isolation from a pedagogical context (Harris et al., 2009; Mishra \& Koehler, 2006).

Although the professional development model that has been in practice does not offer enough time to teachers to learn how to use technology in pedagogic practices, its content does not very much change from the preservice teacher ICT curriculum. The study was one of the first to be conducted in Cameroon to introduce the notion of blending technology, pedagogy and content knowledge in teaching. It is hoped that after attending a professional development programme, teachers will be able to blend technology, pedagogy and content knowledge in the teaching-learning process.

\section{Conclusion}

The TPACK framework constitutes a rich package of knowledge that each teacher should possess to effectively adopt ICTs in his/her classrooms in preparing learners not only for the knowledge economy but for the technology-driven society. The premise of the TPACK framework suggests that if teachers have appropriate knowledge in all of these areas, it can promote pupils' learning. The findings of the survey indicated that teacher-participants reported a better mastery of content knowledge (CK) and pedagogy knowledge (PK). This can be justified by the fact that their pre-service programmes are essentially focused on developing their knowledge of pedagogy and content separately. The weaknesses demonstrated in the three constructs of TK, TPK and TPACK are based on the fact that their professional development programme does not lay emphasis on blending technology, pedagogy and content knowledge. The focus is on empowering them with some basic computer skills and not how to integrate them in the teaching and learning process. By effectively identifying the types of knowledge teachers need (content, pedagogy, technology, contexts and their interactions), teacher trainers will be in a better position to design instructional packages that can empower them to adopt the tool in teaching and learning. For this reason, it is highly recommended that training experts assess teachers' technology adoption needs based on the TPACK framework. This will ensure that the professional development programme is implemented in a way that it integrates technology, pedagogy, and content knowledge-based activities. This might increase the chances of teachers using technology in their classroom after attending a TPACK professional development programme.

\section{References}

Archambault, L., \& Crippen, K. (2009). Examining TPACK among K-12 Online Distance Educators in the United States. Contemporary Issues in Technology and Teacher Education, 9, 71-88.

http://www.citejournal.org/vol9/iss1/general/article2.cfm

Archambault, L., Wetzel, K., Foulger, T. S., \& Williams, M. K. (2010). Professional Development 2.0: Transforming Teacher Education Pedagogy with $21^{\text {st }}$ Century Tools. Journal of Digital Learning in Teacher Education, 27, 4-11. http://dx.doi.org/10.1080/21532974.2010.10784651

Avidov-Ungar, O., \& Nagar, N. M. (2015). ICT Instructors’ Sense of Empowerment and Viewpoint on the Implementation of a National ICT Program. Journal of Computers in Education, 2, 163-182. http://dx.doi.org/10.1007/s40692-015-0030-5

Buckingham, D., \& Willett, R. (2006). Digital Generations: Children, Young People, and New Media. Mahwah, NJ: Lawrence Erlbaum Associates Publishers.

Fru, M. (2011). ICT Readiness in Cameroon Primary Schools: A Case Study of Some Primary Schools Yaounde 6 Sub-Division. A Dissertation Submitted in Partial Fulfilment of an Award of a Master's Degree in Education, Cameroon: University of Yaounde I.

Harris, J. B., \& Hofer, M. (2011). Technological Pedagogical Content Knowledge in Action: A Descriptive Study of Secondary Teachers' Curriculum-Based, Technology-Related Instructional Planning. Journal of Research on Technology in Education, 43, 211-229. http://dx.doi.org/10.1080/15391523.2011.10782570 
Harris, J., Mishra, P., \& Koehler, M. (2009). Teachers’ Technological Pedagogical Content Knowledge and Learning Activity Types: Curriculum-Based Technology Integration Reframed. Journal of Research on Technology in Education, 41, 393-416. http://dx.doi.org/10.1080/15391523.2009.10782536

Harrison, C., Comber, C., Fisher, T., Haw, K., Lewin, C., Lunzer, E., McFarlane, A., Mavers, D., Scrimshaw, P., Somekh, B., \& Watling, R. (2002). ImpacCT2: The Impact of Information and Communication Technologies on Pupil Learning and Attainment. London: DfES and Becta.

Hogan, T. P., Benjamin, A., \& Brezinski, K. (2000). Reliability Methods: A Plans on the Frequency of Use of Various Types. Educational and Psychological Measurement, 60, 523-531. http://dx.doi.org/10.1177/00131640021970691

Inspectorate of Pedagogy in Charge of ICT (2009). Annual Report on the Teaching and Learning of ICT across the School Curriculum.

Inspectorate of Pedagogy in Charge of ICT (2010). Annual Report on the Teaching and Learning of ICT across the School Curriculum.

Inspectorate of Pedagogy in Charge of ICT (2011). Annual Report on the Teaching and Learning of ICT across the School Curriculum.

Kalantzis, M., \& Cope, B. (2008). New Learning. Elements of Science of Education. Cambridge: Cambridge University Press. http://dx.doi.org/10.1017/CBO9780511811951

Kanuka, H. (2006). Instructional Design and eLearning: A Discussion of Pedagogical Content Knowledge as a Missing Construct. The e-Journal of Instructional Science and Technology, 9.

Karsenti, T., Collin, S., \& Harper-Merrete, T. (2012). Pedagogical Integration of ICT: Success and Challenges from 100+ African Schools. Ottawa, ON: IDRC.

Koehler, M. J., \& Mishra, P. (2008). Introducing Technological Pedagogical Content Knowledge. In AACTE Committee on Innovation and Technology (Eds.), Handbook of Technological Pedagogical Content Knowledge (TPCK) for Educators (pp. 3-29). New York: Routledge.

Koehler, M. J., \& Mishra, P. (2009). What Is Technological Pedagogical Content Knowledge? Contemporary Issues in Technology and Teacher Education, 9, 60-70.

Kozma, R. (2005). National Policies That Connect ICT-Based Education Reform to Economic and Social Development. Human Technology, 1, 117-156. http://dx.doi.org/10.17011/ht/urn.2005355

Leu, D. J., Kinzer, C. K., Coiro, J. L., \& Cammack, D. W. (2004). Toward a Theory of New Literacies Emerging from the Internet and Other Information and Communication Technologies. In R. B. Ruddell, \& N. J. Unrau (Eds.), Theoretical Models and Processes of Reading (5th ed., p. 1570). Newark, DE: International Reading Association.

Lieberman, A., \& Pointer Mace, D. H. (2008). Teacher Learning: The Key to Educational Reform. Journal of Teacher Education, 59, 226-234. http://dx.doi.org/10.1177/0022487108317020

McDonald, S. E. (2009). A Model of Teacher Professional Development Based on the Principles of Lesson Study. PhD Thesis, Brisbane: Queensland University of Technology.

Mishra, P., \& Koehler, M. J. (2006). Technological Pedagogical Content Knowledge: A New Framework for Teacher Knowledge. Teachers College Record, 108, 1017-1054. http://dx.doi.org/10.1111/j.1467-9620.2006.00684.X

Moore, D. S., \& McCabe, G. P. (2005). Introduction to the Practice of Statistics (5th ed.). New York: W.H. Freeman \& Company.

Niess, M. L. (2008). Knowledge Needed for Teaching with Technologies: Call It TPACK. AMTE Connections, 17, 9-10.

Niess, M. L., Ronau, R. N., Shafer, K. G., Driskell, S. O., Harper, S. R., \& Johnston, C. (2009). Mathematics Teacher TPACK Standards and Development Model. Contemporary Issues in Technology and Teacher Education, 9, 4-24.

Nkwenti Ndongfack, M. (2010). ICT Integration in Cameroon Primary Schools: A Case Study of Government Primary Practicing School Angele, South Region. A Dissertation Submitted in Partial Fulfillment of an Award of a Master's Degree in Instructional Design and Technology, Kuala Lumpur: Open University Malaysia.

Nkwenti Ndongfack, M. (2014). Development and Evaluation of a Technology Integration Model for Primary School Teachers to Achieve Cameroon's 2035 Vision. A Thesis Submitted in Partial Fulfillment of an Award of a PhD in Educational Technology, Kuala Lumpur: Open University Malaysia.

Nkwenti Ndongfack, M. (2015). Mastery of Active and Shared Learning Processes for Techno-Pedagogy (MASLEPT): A Model for Teacher Professional Development on Technology Integration. Creative Education, 6, 32-45.

http://dx.doi.org/10.4236/ce.2015.61003

OECD (2009). 21st Century Skills and Competences for New Millennium Learners in OECD Countries. OECD Education Working Papers, No. 41, OECD publishing, Organization for Economic Co-operation and Development.

http://dx.doi.org/10.1787/224131752784 
Partnership for the 21st Century (2009). A Framework for 21st Century Learning. Washington DC: Partnership for the 21st Century.

Republic of Cameroon, Ministry of Basic Education (Department of Projects and Cooperation) (2011). Statistical Year Book.

Republic of Cameroon, Ministry of Basic Education (Inspectorate of Pedagogy in Charge of Computer Science Education) (2007a). Information and Communication Technology Policy and Strategies Plan.

Republic of Cameroon, Ministry of Basic Education (Inspectorate of Pedagogy in Charge of Computer Science Education) (2007b). Information and Communication Technology Framework and strategies Plan for Basic Education Sub-Sector.

Richardson, S. (2009). Mathematics Teachers Development, Exploration, and Advancement of Technological Pedagogical Content Knowledge in the Teaching and Learning of Algebra. Contemporary Issues in Technology and Teacher Education, 9, 117-130. http://www.citejournal.org/vol9/iss2/mathematics/article1.cf

Schmidt, D. A., Baran, E., Thompson, A. D., Koehler, M. J., Shin, T. S., \& Mishra, P. (2009). Technology, Pedagogy and Content Knowledge (TPACK): The Development and Validation of an Assessment Instrument for Pre-Service Teachers. Paper Accepted for Presentation at American Educational Research Association (AERA) Annual Meeting, San Diego.

Schmidt, D., Seymour, J., Sahin, E., \& Thompson, A. (2008). Developing Effective Technological Pedagogical and Content Knowledge (TPACK) in PreK-6 Teachers. In K. McFerrin, R. Weber, R. Carlsen, \& D. A. Willis (Eds.), Proceedings of Society for Information Technology \& Teacher Education International Conference 2008 (pp. 5313-5317).

Shulman, L. S. (1986). Those Who Understand: Knowledge Growth in Teaching. Educational Researcher, 15, 4-14. http://dx.doi.org/10.3102/0013189X015002004

Shulman, L. S. (1987). Knowledge and Teaching: Foundations of the New Reform. Harvard Educational Review, 57, 1-22. http://dx.doi.org/10.17763/haer.57.1.j463w79r56455411

The Research Advisors (2006). http://research-advisors.com/tools/SampleSize.htm

Thorndike, R. M. (2005). Measurement and Evaluation in Psychology and Education. Upper Saddle River, NJ: Pearson Prentice Hall.

Valanides, N., \& Angeli, C. (2006). Preparing Pre-Service Elementary Teachers to Teach Science through Computer Models. Contemporary Issues in Technology and Teacher Education, 6, 87-98. 